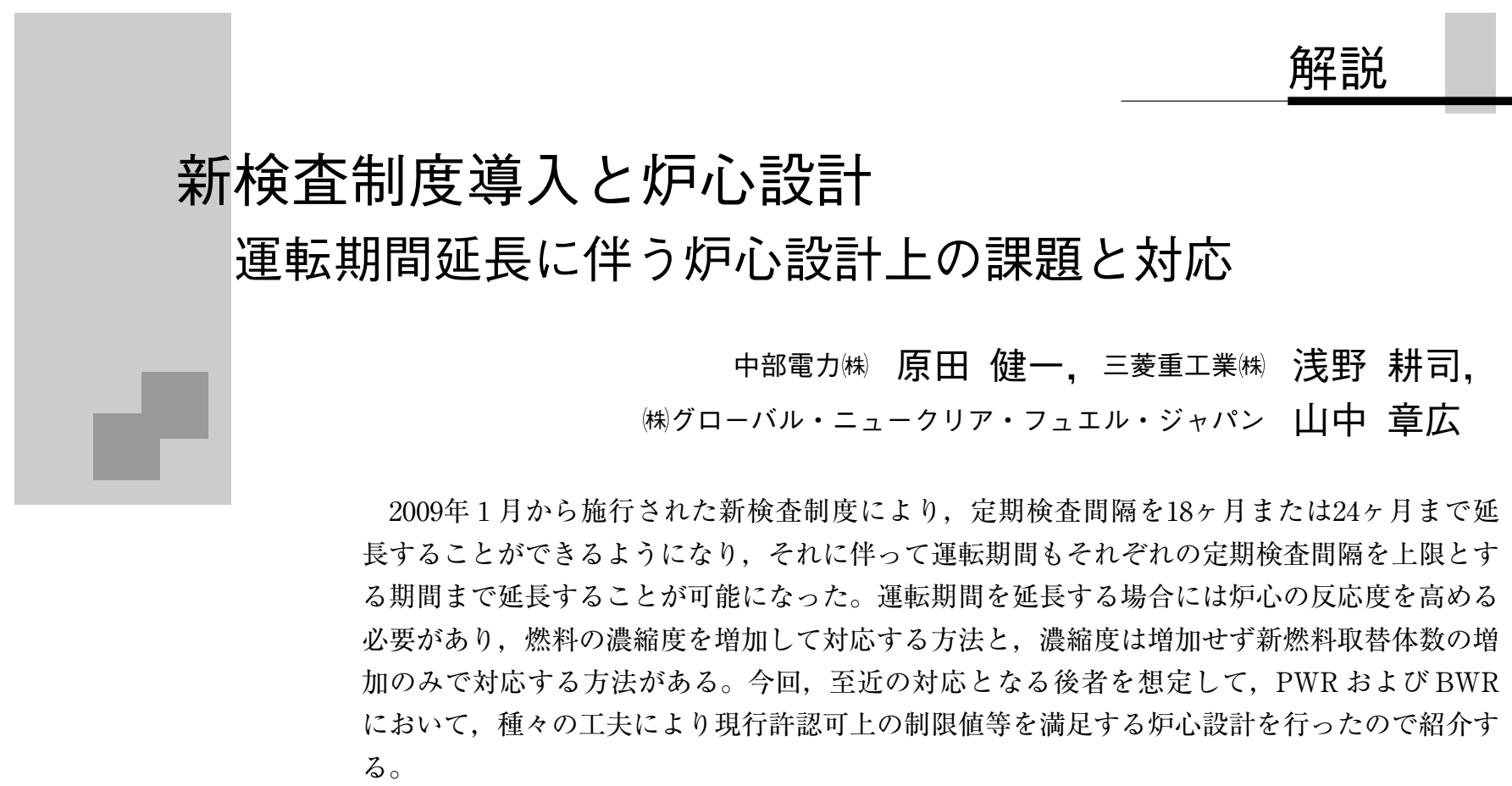

\section{I ．はじめに}

\section{1. 原子力発電の設備利用率向上}

国内の電力会社ではこれまで, 原子力発電所の設備利 用率向上を目指して, 海外の原子力発電所で実績のある 「定格熱出力運転」,「原子炬出力の増加」および「24ケ月 運転を目指した運転期間の延長」を国に要望してきた。 以下，その現状について概観する。

\section{（1）定格熱出力運転}

従来は定格電気出力運転を行っていたが，定格熱出力 運転とすることにより, 海水温度の低い冬場に扔いて タービンの効率が増加するため, 定格出力以上に電気出 力を増加できるメリットがある。定格熱出力運転は, 2000 年末に導入手続きが国で制定され，2002年から国内の原 子力発電所で導入されてきた。現在では原子力発電所約 1 基に相当する電気出力が創出されている。

\section{（2）原子炉出力の増加}

欧米では燃料の熱的制限值に対する運転裕度を確保し て数\%の出力増加を行っており, 発電機等の設備改造を 伴うものでは約 $20 \% の$ 出力増加を行っている発電所も存 在している。

国内においては，具体的な計画の検討が進められてい る約 $5 \%$ の出力増加を対象として，原子炉の安全性，設 備の健全性，保守・運転管理への影響などを検討評価す るために，2009年 1 月に総合資源エネルギー調查会原子 力安全・保安部会原子炉安全小委員会に原子炉熱出力向

Implementation of New Inspection System and Core Design for Extended Cycle Operation:Kenichi HARADA, Koji ASANO, Akihiro YAMANAKA

(2010年 2 月 4 日 受理)
上ワーキンググループが設置された。

\section{（3） 24 ヶ月運転を目指した運転期間の延長}

米国では当初，日本と同じ約 1 年間の運転期間であっ たが，1990年代から，19ケ月，24ケ月と運転期間を延 長してきており，設備利用率の向上に大きく寄与してい る。

国内においては, 原子力安全・保安院から示された「保 全プログラムを基礎とする検査の導入について(新検查 制度)」(2008年 6 月)の考え方に基づいて，原子炉の運転 期間を延長する場合の導入手続きとして, 関係する経済 産業省令が2008年 8 月に改正され，2009年 1 月から施 行された。この改正により, 段階的な運用になるが, 定 期検查間隔を18ケ月または24ケ月まで延長することがで きるようになり，それに伴って運転期間もそれぞれの定 期検査間隔を上限とする期間まで延長することが可能と なった。

以下では, 新検査制度の導入に伴い可能となった運転 期間の延長のための炬心設計について解説する。

\section{2. 新検査制度と運転期間延長}

新検査制度の概要を第 1 図に示す。今回の見直しで は，科学的・合理的判断に基づいて検查制度を充実する ことを目的に，新たな取組みが追加されている1”。

「保全計画の届出と国による事前確認」では, 事業者が 現状の機器の状態と現状保全の妥当性評価結果に基づい て保全計画を作成して国に事前に届け出て, 国が保全計 画を確認し，事業者の保全活動が継続的に改善されてい ることを確認する。「設備の傷み具合のデー夕収集と点 検への反映を義務づけ」では, 事業者が経年劣化状況や 過去のトラブルを踏まえて, 保全活動の評価・改善を繰 


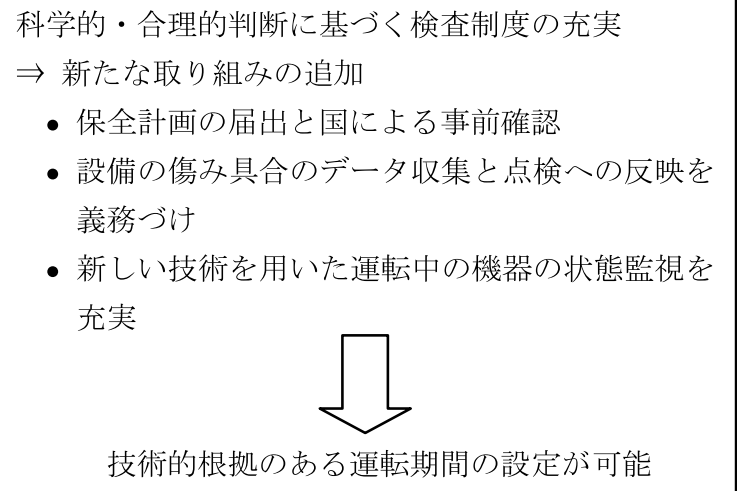

第 1 図新検査制度の概要

り返すことを義務付けている。「新しい技術を用いた運 転中の機器の状態監視を充実」では，振動診断，潤滑油 診断，赤外線サーモグラフィー診断等の技術の活用によ り, 分解点検を行うことなく機器の異常の兆候をいち早 く把握できることを目的としている。

これらの新たな取組みの追加により，従来は法律によ り一律13ヶ月としていた運転期間に対し，プラントごと に技術的根拠のある運転期間の設定が可能となった。

実際に運転期間を延長する場合，その運転期間に対し 定格出力が維持できるように炉心の反応度を高める必要 があり, 基本設計である燃料の濃縮度を増加して新燃料 取替体数を増加して対応する方法と，基本設計を変更せ ずに新燃料取替体数の増加のみで対応する方法がある。 前者では原子炉設置変更許可の申請が必要であり, 後者 では現行の原子炉設置許可の基本設計である制限值等を 満足させる必要がある。

至近の対応としては基本設計を変更しない後者の方法 となるが，新燃料取替体数の増加を含め，運転期間延長 が炉心特性に種々の影響を及ぼす。その評価のための基 本的な考元方の取りまとめを目的として，2009年 1 月 に, 総合資源エネルギー調查会原子力安全・保安部会原 子炉安全小委員会に安全評価ワーキンググループ(長期 サイクル炉心評価)が設置され，代表的な PWR 㧤よび BWR を対象として運転期間延長が炉心特性, 安全評価 等に及ぼす影響について検討された。

本稿では，運転期間を延長したPWR およびBWRに おいて, 現行の原子炉設置許可の制限值等を満足する炉 心を設計したので，その主要特性とともに紹介する。

\section{II ．PWR の炉心設計}

\section{1. まえがき}

燃料仕様(濃縮度やガドリニア濃度など)を現状の設置 許可条件のまま運転期間を延長するには，炉心の余剩反 応度を増加させるために原子炬に装荷する新燃料の取替 体数を増加させる必要がある。この場合においても，炉 心の特性が原子炉設置許可申請書本文に適合したもので あることを確認する必要がある。本章では，基本設計な
いし基本的設計方針に則した運転が可能である運転期間 として，16ヶ月(原子炉起動から停止までの期間)まで延 長した場合の，代表プラントにおける炉心特性への影響 評価の結果を紹介する。

\section{2. 運転期間の延長}

現行の燃料仕様での運転期間と新燃料取替体数の関係 は，代表プランドにおいて運転期間を13ヶ月，16ケ月 とした場合，それぞれ60体，72体程度となる。このよう に，16ケ月運転では大半の燃料が 3 サイクル使用され， 現行炉心と同等の燃料運用効率を維持することができ る。さらに, 16ケ月程度までの運転期間の延長であれば, それによる炉心特性の変動分が，現在の各安全解析使用 值に見込んでいる炉心の変動の範囲内となり, 従来の取 替炉心設計の延長線上での対応が可能になると想定され る。

\section{3. 炉心特性への影響}

一般に，運転期間延長のための新燃料取替体数増加や サイクル燃燒度増加により，

一サイクル初期の余剩反応度の増加

一炉心内出力分担の変化

一反応度特性の変化 等の現象が炉心特性に影響を与えることが考えられる。 比較的短い運転期間の延長であればこれらの影響は小さ く，従来の取替炕心の設計手法を適用できると想定され るため，今回は運転期間を16ヶ月とした代表プラントに おいて各現象による影響を評価した。

\section{（1） サイクル初期の余剩反応度の増加}

新燃料取替体数が増加するとサイクル初期の余剩反応 度は増加する。PWR においては, 余剩反応度は 1 次冷 却材中のホウ素により制御するため，ホウ素濃度は増加 することとなる(第 2 図)。そのため，原子炉設置許可申 請書に記載されているホウ素濃度に関連するパラメー夕 への影響を評価し, その結果, 現行記載值の範囲内で取 替炉心を構築できることを確認した。

(2) 炉心内出力分担の变化

新燃料取替体数の増加により, 反応度の高い新燃料が 隣り合って炬心に装荷され，出力ピーキングは若干大き くなる可能性がある。代表プラントにおいては，燃料配 置の工夫により, 出力ピーキングは現行安全解析使用值 の範囲内となることを確認した。16ヶ月炉心の燃料配置 例を第 3 図に示す。実機取替炉心では，出力ピーキング は, 従来から取替炬心の安全性確認項目の一つとして取 替炉心設計のつど確認しており，運転期間を延長した 16ヶ月炉心においても同様に評価することで核設計上問

a) 燃料集合体体数 193 体 (燃料集合体最高燃焼度を $55 \mathrm{GWd} / \mathrm{t}$ と した $17 \times 17$ 型燃料集合体を装荷 $)$, 定格電気出力約 120 万 $\mathrm{kW}$ の 4 ループプラントを対象としている。 


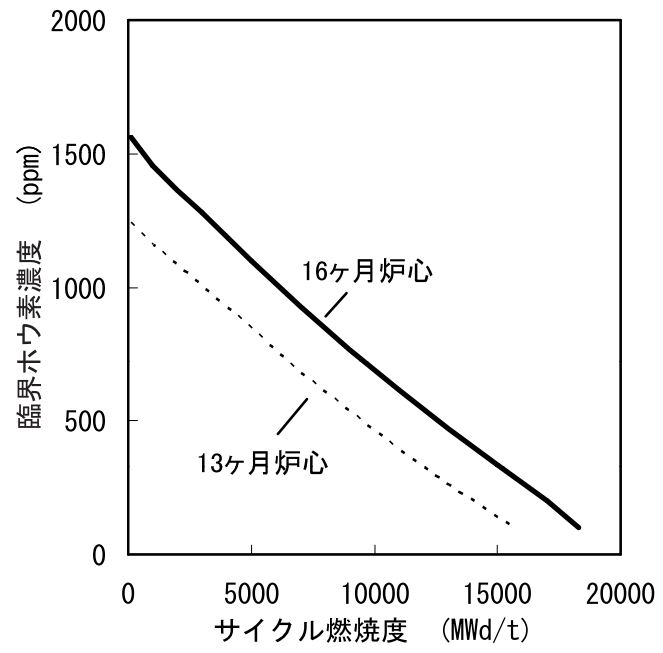

第 2 図 燃焼に伴うホウ素濃度の推移

題ないことを確認することになる。

\section{（3） 反応度特性の変化}

反応度特性についても, 出力ピーキングと同様に, 従 来から取替炉心ごとに核設計上問題ないことを確認して いる。反応度係数の一つである減速材温度係数は, 減速 材温度が変化することによる反応度効果であり, 減速材 温度が上昇した場合には, 減速材密度の減少による減速 能低下に起因する負の反応度効果と, 冷却材中のホウ素 原子数の減少による正の反応度効果から決定されるもの であり (第 4 図), 出力運転中は常に負でなければならな い。この減速材温度係数は, サイクル初期のホウ素濃度 が高くなることにより，若干，正側(負值であるが絶対 值が小さい方向)になる傾向が認められるが，ガドリニ ア入り燃料の装荷体数や装荷位置を工夫することで， サ イクル初期のホウ素濃度を低下させ, 減速材温度係数が 出力運転状態で負になるよう設計することができる。以 上から, 反応度特性についても, 現行安全解析使用值の 範囲内で取替炬心を構築することが可能である。

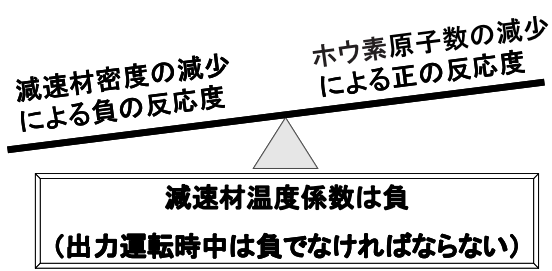

第 4 図 減速材温度係数

\section{4. 結 論}

16ヶ月程度への運転期間の延長では，炉心特性に大き な影響が生じないため，現行炉心と同様の基本設計ない し基本的設計方針に則した取替炉心を構成することがで きるとの結論に至った。

\section{III．BWR の炉心設計}

\section{1. まえがき}

基本設計を変更しない範囲で運転期間の延長を行う場 合，より長期間にわたって原子炉の特性が種々の運転制 限值等を満足するように，燃料配置・制御棒パターンの 工夫およびガドリニア設計の最適化が必要となる。本章 では代表プラントりにおいて，運転期間を19ケ月に延長 した場合の炉心設計を実施した結果を紹介する。13ケ月 運転に比べて, 新燃料取替体数は全炉心の約 $1 / 4$ 程度か ら約 $1 / 3$ 程度に増加する。

\section{BWR 炉心設計の概要}

燃料核設計においては, 基本設計としての濃縮度を決 定するとともに, 設計条件の運転期間中に平坦な余剩反 応度特性を有し, サイクル末期においてガドリニアが燃 え尽きるようにガドリニアの濃度と本数を調整する。

燃料配置としては, 現行の13ケ月運転では, コントロー

b) 燃料集合体体数 764 体 (燃料集合体最高燃焼度を $55 \mathrm{GWd} / \mathrm{t}$ とした $9 \times 9$ 型燃料集合体を装荷 $)$, 定格電気出力約 110 万 $\mathrm{kW}$ のプラントを対象としている。

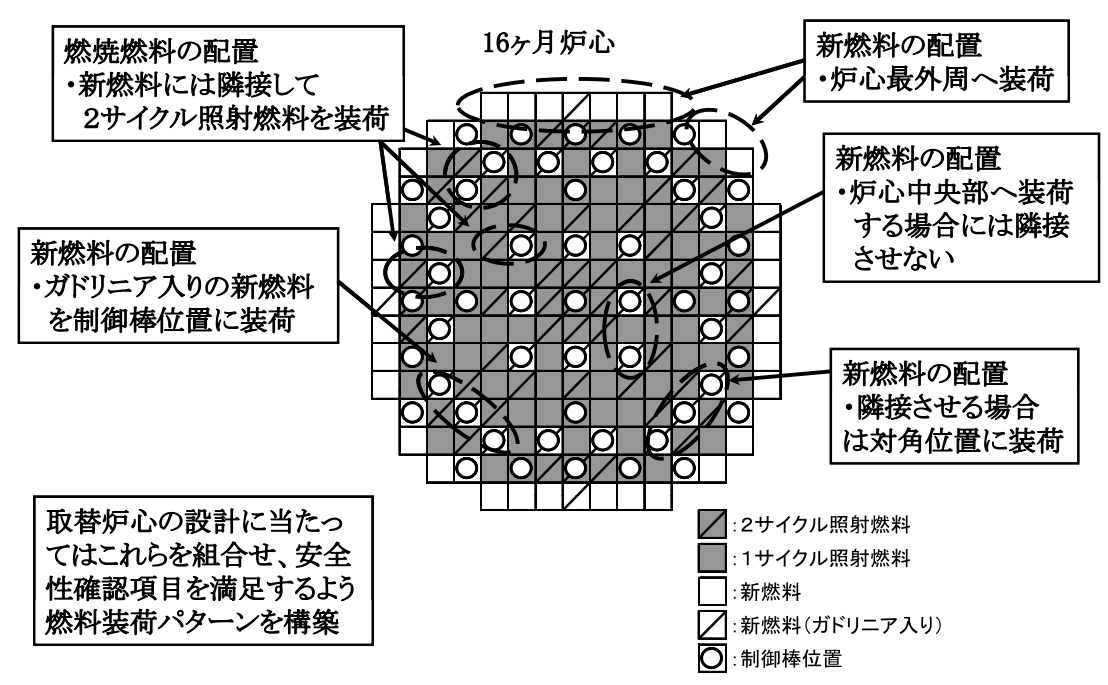

第 3 図 装荷パターンの工夫例 
ルセル炉心が多く採用されている。これは，運転中の反 応度補償に用いる制御棒の周囲 4 体に燃焼が進んで反応 度が小さくなった燃料集合体を配置(「コントロールセ ル」という)する炬心設計であり，制御棒引抜き時に当該 制御棒周辺の出力上昇を小さくできることから，制御棒 引抜き時の負荷損失が小さくなり運転中の設備利用率を 向上させることが可能である。

上記の燃料核設計，燃料配置および制御棒計画は，最 大線出力密度, 最小限界出力比, 炉停止余裕などの炉心 特性が運転制限值を満たすように決定される。さらに, プラント過渡事象に及ぼす影響の指標として, 主要な反 応度係数も重要である。

\section{19 ケ月運転炉心設計}

13ヶ月運転用に設計された燃料をそのまま用いて19ケ 月程度の運転を行う場合には, サイクル期間中でのガド リニア燃焼特性が最適化されておらず，余剩反応度が高 くなる傾向となる。一方, 運転期間に応じてガドリニア 設計を最適化すれば，平坦な余剩反応度を得ることがで きる。余剩反応度の例を第 5 図に示す。

本節では，ガドリニア設計を変更しない場合と最適化 した場合のおのおのについて，運転制限值を満足する炉 心を設計した結果を紹介する。燃料配置と制御棒挿入位 置を第 6 図に示す。新燃料は, 13ケ月運転の場合と同様, 炬心最外周を除く位置に，隣接させずほぼ均等に配置し ている。

（1）燃料配置・制御棒パターンの工夫

ガドリニア設計を変更しない炉心の燃料配置として は，コントロールセルを構成しないコンベンショナル炉 心を採用した(第 6 図左)。

コントロールセル炉心では，コントロールセル以外の 場所に新燃料または燃焼の進んでいない反応度の大きい 燃料が集まりやすい傾向となる。特に，運転期間の延長 を行った場合には，新燃料取替体数が増加し，反応度が 大きい燃料が多くなること，および挿入される制御棒の 数が増加するため, 必要な数のコントロールセルを作成

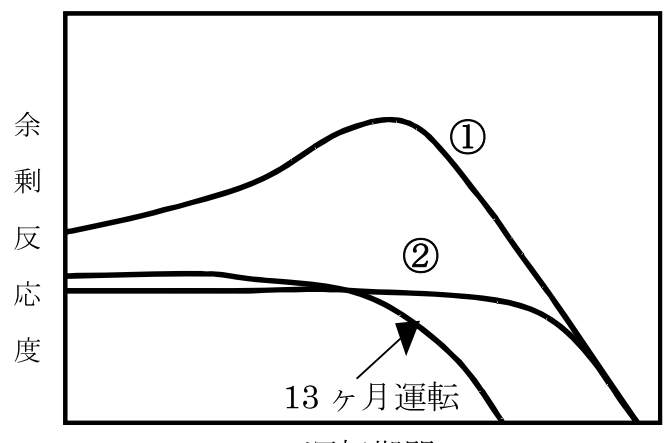

運転期間

第 5 図余剩反応度の例 (1)(2)は19ケ月運転) (1)はガドリニア設計を変更しない場合, (2)はガドリニア設計を最適化した場合

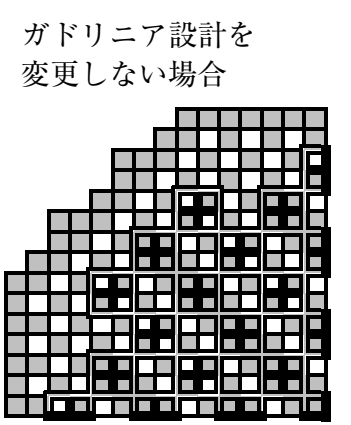

ガドリニア設計を 最適化した場合

\section{$\square$ 新燃料 \\ 口1または2サイクル照射燃料}

回運転中に制御棒が挿入される位置

第 6 図燃料配置 (1/4炬心) と制御棒挿入位置

することが困難になる可能性がある。

これに対してコンベンショナル炉心では，運転期間の 延長を行った場合でも，反応度の大きい燃料と小さい燃 料を比較的均等に配置できるため，炉心設計上の制約を 少なくできる。海外ではすでに24ヶ月程度の運転を行っ ている例があるが，コントロールセルを配置しない炉心 とすることが多い。なおコンベンショナル炉心では，炉 心全体を均一に燃焼させるため，制御棒の挿入位置を 数力月ごとに変更する運用が一般的である(第 7 図)。

（2） ガドリニア設計の最適化

余剩反応度の増加への対策として, 運転サイクル長さ に適したガドリニア濃度に増加させるとともに，サイク ル初期の余利反応度を調整するためにガドリニア入り燃 料棒の本数を変更した設計を採用し，19ヶ月程度の運転 に適した余剩反応度特性が得られるようにすることがで きる。なお，ガドリニア設計の変更は，運転中の余剩反 応度特性を改善する目的で，これまでにも基本設計の範 囲内での実績を有している。

ガドリニア設計を最適化することによって，余剩反応
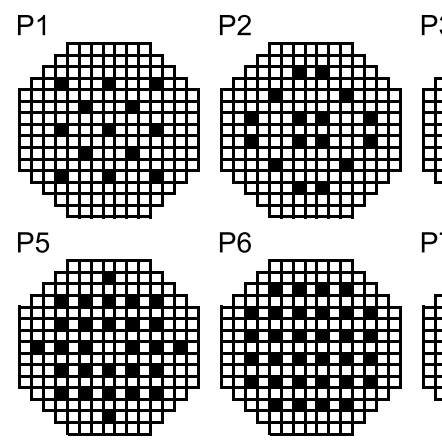

$\mathrm{Pg}$

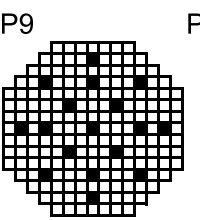

P10
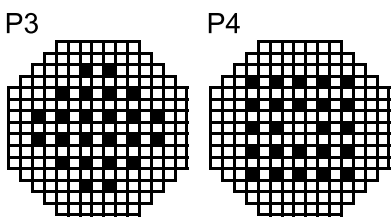

P7

P8
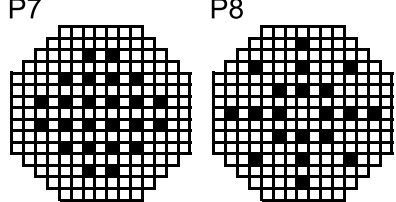

P11

$\mathrm{P} 12$
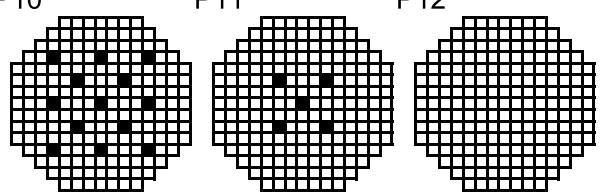

第 7 図コンベンショナル炉心の制御棒パターン

（サイクル初期の P 1 からサイクル末期の P 12に 向かって挿入制御棒位置口を変更させている) 
度が適切に設定されているため，コントロールセル炬心 を採用することができる(第 6 図右 $)$ 。コントロールセル の数も現行炉心程度であり, 反応度の大きい燃料と小さ い燃料とを比較的均等に配置することができる。また， 運転期間を通じて余剩反応度が平坦であるため, 制御棒 パターンの変更も少ない。なお第 6 図右では, 一部のコ ントロールセルに新燃料が配置されているが，当該制御 棒は運転サイクル後半でのみ挿入される。

\section{（3） 反応度係数への影響}

プラント過渡事象に影響を及ぼす重要なパラメータと して，減速材ボイド係数およびドップラー係数の変化に ついて評価した。その結果，いずれの炉心においても， 13ヶ月炉心と同等の特性であることが確認できた。

\section{4. 結 論}

以上の通り，19ケ月程度への運転期間の延長であれ ば，燃料配置・制御棒パターンの工夫あるいはガドリニ ア設計の最適化によって, 基本設計を変更することな く，運転制限值を満足する炉心を設計することができ た。

\section{N.おわりに}

2009年10月に，安全評価ワーキンググループ（長期サ イクル炉心評価)の成果が, パブリックコメントを経て, 報告書「原子炉運転期間の設定の妥当性確認に関する評 価の基本的考え方」にまとめられた ${ }^{2)}$ 。これにより，運転 期間延長に必要な評価が具体化され, 今後の運転サイク ルにおける運転期間延長がいよいよ現実のものとなっ た。各電力会社においては, 着々とその準備を整えてい るところである。

さらに, より一層の運転期間延長と効率的な燃料の運
用を目指して，基本設計である燃料の濃縮度を増加する 方法についても検討が進められている。これらを通じ て, また原子炉出力の増加も併せ, 既存の原子力発電所 の利用率向上を推進していく。

\section{一参 考 資 料一}

1）経済産業省原子力安全・保安院パンフレット「検査制度 見直しのご案内」.

2）総合資源エネルギー調查会原子力安全・保安部会原子炉 安全小委員会安全評価ワーキンググループ(長期サイク ル炉心評価）報告書「原子炉運転期間の設定の妥当性確認 に関する評価の基本的考え方」(2009年10月26日).

著者紹介

原田健一（はらだ・けんいち）

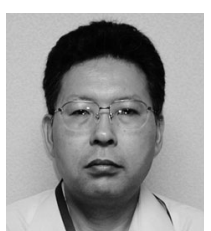
中部電力(株) (専門分野/関心分野) BWR 燃料設計, BWR 炉心設計

\section{浅野耕司(あさの・こうじ)}

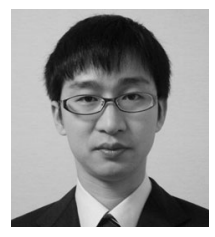

三菱重工業(株)

(専門分野/関心分野) 原子炉物理学, PWR 炉心設計

\section{山中章広 (やまなか・あきひろ)}

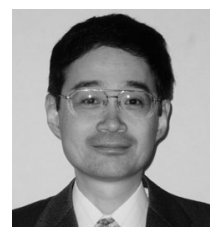

(株)グローバル・ニュークリア・フュエル． ジャパン

(専門分野/関心分野) BWR 炉心設計 